\title{
Women employment and empowerment - An analysis with special reference to Keonjhar, Odisha
}

\author{
VIJAYETA PRIYADARSHINI* AND LIPSA DASH ${ }^{1}$ \\ Department of Home Science, Govt. Women's College, KEONJHAR (ODISHA) INDIA \\ ${ }^{1}$ Department of Home Science, Sambalpur University, BURLA(ODISHA) INDIA
}

\begin{abstract}
Women development plays an important role in nation's economy. The society can march towards development only when it accepts the women participation, grants responsibility and utilizes her ability. India has witnessed a positive transformation in women's employment and economic development. Present study was conducted among 110 working women of Keonjhar district of Odisha. Various degree of empowerment was observed in fields of social, financial, legal empowerment. The study revelled that decision making was most restricted in financial matters.
\end{abstract}

KEY Words : Employed women, Empowerment, Socio-econimc empowerment, Legal awareness

View Point Article : Priyadarshini, Vijayeta and Dash, Lipsa (2016). Women employment and empowerment - An analysis with special reference to Keonjhar, Odisha. Internat. J. Home Sci. Extn. \& Comm. Manage., 3 (1): 31-36.

Article History : Received : 01.10.2015; Revised : 17.12.2015; Accepted : 28.12.2015

\footnotetext{
* Author for correspondence
} 